\title{
MANFAAT KANOPI POHON DALAM UPAYA PENYIMPANAN DAN DAYA SERAP KARBON DI KAWASAN PERUMAHAN
}

\author{
The Benefit of Trees Canopy for \\ Carbon Storage and Sequestration in \\ Residential. Case Study: Bukit \\ Cimanggu City and Taman Yasmin, \\ Bogor \\ Purwanti Lukmanniah
Alumni Departemen Arsitektur
Lanskap, Fakultas Pertanian, IPB \\ Indung Sitti Fatimah Staf Pengajar \\ Departemen Arsitektur Lanskap, \\ Fakultas Pertanian IPB \\ Email : isfatimah.iin@gmail.com
}

\begin{abstract}
Residential development in urban areas was requiring extensive landscape changes. This development caused the decreases of urban green land. The high rate of $\mathrm{CO}_{2}$ in the atmosphere is one impact of the reduction of green land in urban area.The existing plants are unable to sequester the amount of $\mathrm{CO}_{2}$ in atmosphere. Plans especially trees are landscape elements which can reduce $\mathrm{CO}_{2}$ in the atmosphere through the photosynthesis process. With this research we can see and know how large the benefits of tree for carbon storage and sequestration in residential. This research was held in two residential that Bukit Cimanggu City and Yasmin, Tanah Sareal, Bogor. Analysis was done to spatial data using ArcView and CITYgreen 5.4 extension. This report showed that the greater of trees canopy and trees number then the greater of the amount of carbon storage and sequestration. The result of this research are tabular data and spatial data with simulations examples of open green space (trees) from analysis area in each residential.
\end{abstract}

Keywords: Tree Canopy, Residential Landscape, Carbon Storage and Sequestration, CITYgreen 5.4

\section{PENDAHULUAN}

\section{Latar Belakang}

Pertumbuhan penduduk telah meningkatkan permintaan kebutuhan lahanperumahan. Hal ini mendorong terjadinya perubahan fungsi lahan yang didominasi oleh ruang terbuka hijau(RTH) menjadi lahan perumahan. Pembangunan perumahan untuk menampung jumlah penduduk yang bertambah pesat, memerlukan luas lahan yang besar pula (Wiradisuria, 1983).

Kota Bogor sebagaikota penyangga bagi kota besar disekitarnya memiliki tingkat pengembangan perumahan yang cukup tinggi.Pesatnya pengembangan perumahan memberikan dampak positif dan negatif bagi perkembangan kota. Dampak positifnya, yaitu meningkatkan kesejahteraan masyarakat. Sementara dampak negatifnya adalah timbulnya persoalan lingkungan hidup yaitu rusaknyastruktur dan fungsi dasar ekosistem pendukung kehidupan manusia. Bentuk kerusakan struktur dan fungsi tersebut berupa peningkatan kadar $\mathrm{CO}_{2}$ di udara sehingga terjadi pemanasan global (global warming). Dahlan (2007) dalam penelitiannya mengemukakan bahwa rerata konsentrasi gas $\mathrm{CO}_{2}$ di Kota Bogor pada Tahun 2006/2007 adalah sebesar 389,89 ppmv. Nilai ini telah melebihi nilai baku mutu yang seharusnya yaitu sebesar 350 ppmv. Peningkatan konsentrasi gas $\mathrm{CO}_{2}$ di Kota Bogor saat ini sangat menghawatirkanmaka diperlukan pengendalian jumlah emisi diudara. Hal ini dilakukan dengan memperbesar kapasitas penyimpanan dan daya serap karbon agar konsentrasi ambient $\mathrm{CO}_{2}$ tidak terus meningkat.

Kapasitas penyimpanan dan daya serap karbon dapat ditingkatkan dengan vegetasi pada kawasan. Vegetasi tersebut mengurangi $\mathrm{CO}_{2}$ di atmosfer melalui proses fotosintesis (McPherson dan Simpson, 1999). Vegetasi pohon sebagai elemen lanskap mampu menyerap dan menyimpan $\mathrm{CO}_{2}$ (dalam biomassa pohon) diudara lebih besar dibandingkan tumbuhan yang lain. Nilai serapan $\mathrm{CO}_{2}$ vegetasi pohon yaitu 58,26 ton/ha untuk jenis tanaman hutan sedangkan 3.30 ton/hauntuk jenis tanaman semak (Iverson et al., 1993; Tinambunan RS, 2006). Berdasarkan hasil tersebut, pohon memiliki peranan yang sangat penting dalam mereduksi $\mathrm{CO}_{2}$ di udara.

Oleh karena itu, dilakukan penelitian mengenai manfaat keberadaan pohon dalam menanggulangi permasalahan yang timbul akibat pengurangan luasan RTH kota, yaitu salah satunya dengan menghitung manfaat kanopi pohon dalam menyimpan dan menyerap karbon pada kawasanperumahan. Pada akhirnya, akan diperoleh luasan kanopi yang mampu menunjang kenyamanan kawasan perumahan tersebut.

\section{Tujuan}

Tujuan dari penelitian ini adalah untuk melihat dan mengetahui seberapa besar manfaat keberadaan pohon dalam menyimpanan dan menyerap karbon di kawasan perumahan dengan cara:menghitung luas kanopi dan non kanopi pada masing-masing kawasan perumahan dengan menggunakan ekstensi CITYgreen 5.4,

1. menduga serta membandingkan hasil pendugaan manfaat kanopi pohon dalam penyimpanan dan penyerapan karbon pada masing-masing kawasan perumahan,

2. membuat prediksi kondisi kawasan perumahan saat ini dan beberapa tahun kedepan dengan simulasi pengembangan luasan kanopi pohondengan menggunakan ekstensi CITYgreen 5.4.

\section{Manfaat}

Manfaat dari penelitian ini adalah: 
1. menjadi bahan masukan bagi pemerintah daerah Kota Bogor dalam menyusun kebijakan perencanaan lanskap kawasan perumahan,

2. menjadi bahan masukanbagi developer dalam merencanakan dan mendesain suatu lanskap kawasan perumahan,

3. masyarakat dapat memahami pentingnya keberadaan pohon bagi kehidupan dan lingkungannya.

\section{Lokasi dan Waktu Penelitian}

Penelitian dilakukan di Perumahan Bukit Cimanggu City dan Perumahan Taman Yasmin, Bogor (Gambar 2). Kegiatan penelitian ini dilaksanakan selama 7 bulan, dimulai dari bulan Maret 2010 hingga bulan November 2010, kemudian dilanjutkan dengan kegiatan penyusunan skripsi.

\section{Kerangka Pikir}

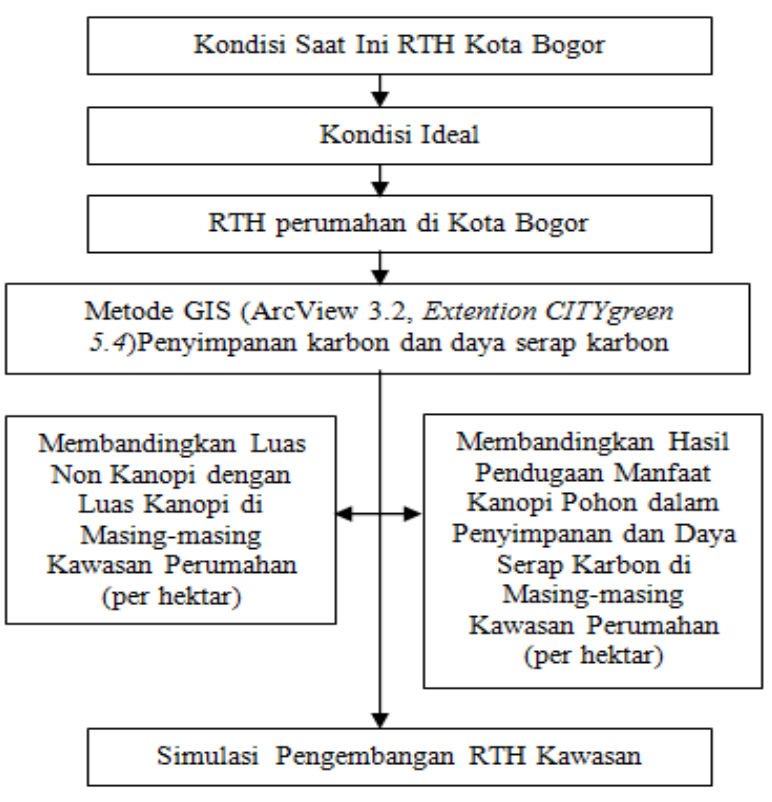

Gambar 1. Kerangka Pikir Penelitian

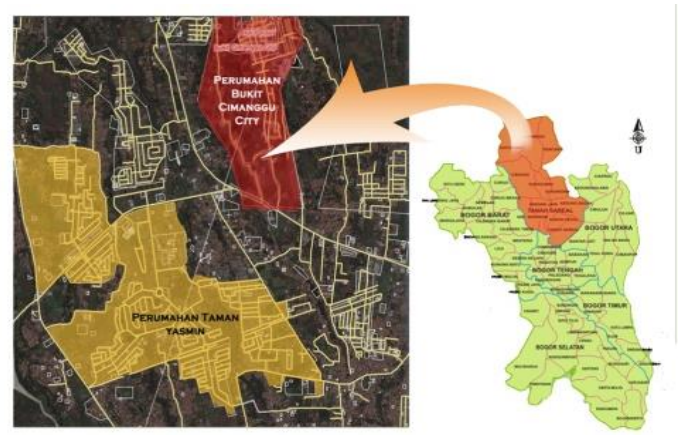

Gambar 2. Peta Lokasi Penelitian

\section{Batasan Penelitian}

Penelitian dibatasi hingga tahap analisis dengan produk akhir berupa simulasi RTH dalam bentuk spasial dan tabular. Adapun batasan yang digunakan pada penelitian, yaitu:

1. Pengukuran kelompok rumah berdasarkan kesamaan persentase penutupan lahan oleh kanopi pohon dan tipe rumah yang sama (atap).

2. Perhitungan nilai manfaat pohon dari site percontohan berdasarkan pendugaan karbon yang tersimpanserta daya serap karbon dengan menggunakan analisis CITYgreen.

\section{METODE}

Metode yang digunakan dalam penelitian ini adalah pengkajian terhadap data sekunder (foto citra satelit). Tahapan penelitian ini dilakukan sampai tahap analisis. Adapun tahapan dalam análisis data dengan menggunakan ekstensi CITYgreen 5.4, yaitu:

1. Persiapan citra satelit. Pada penelitian ini, data raster yang digunakan adalah citra satelit Quickbird 2006 Kota Bogor yang mencakup dua kawasan perumahan di Kota Bogor, yaitu Kawasan Perumahan Bukit Cimanggu City dan Taman Yasmin yang telah memiliki referensi geografis.

2. Penentuan batas area studi (lokasi penelitian).

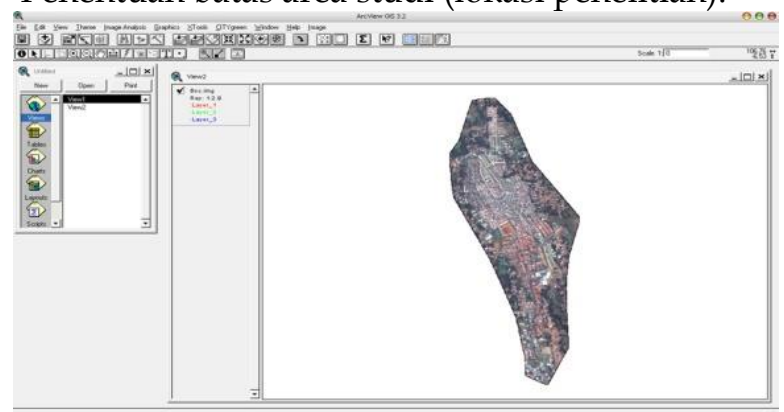

Gambar 3. Tampilan Digitasi Citra Perumahan Bukit Cimanggu City Bogor

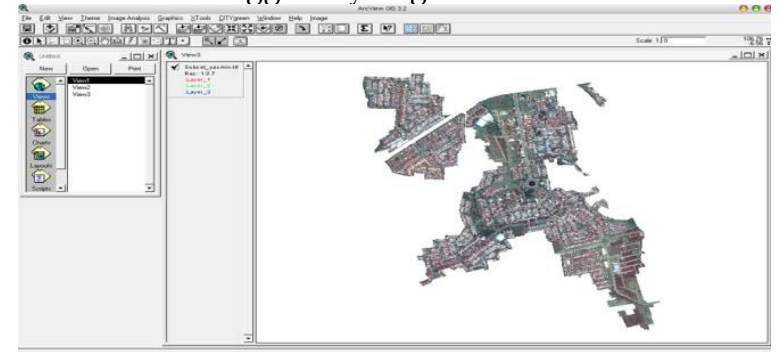

Gambar 4. Tampilan hasil digitasi citra Perumahan Taman Yasmin Bogor

3. Digitasi site, theme canopy dan non canopy

4. Input data. Memasukkan data hasil survei lapang dengan cara meng-add/update data atribut dari theme canopy dan non canopy. Khusus untuk theme 


\section{LUKMANNIAH, FATIMAH}

canopy dibutuhkan data/informasi mengenai nama spesies pohon, lebar tajuk, tinggi pohon, D.B.H, nilai kondisi kesehatan dan pertumbuhan pohon.

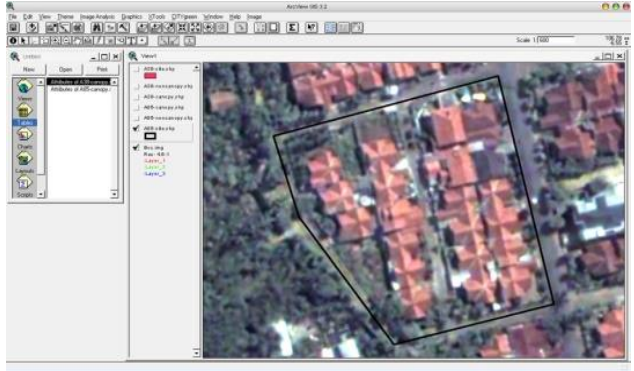

(a) Site

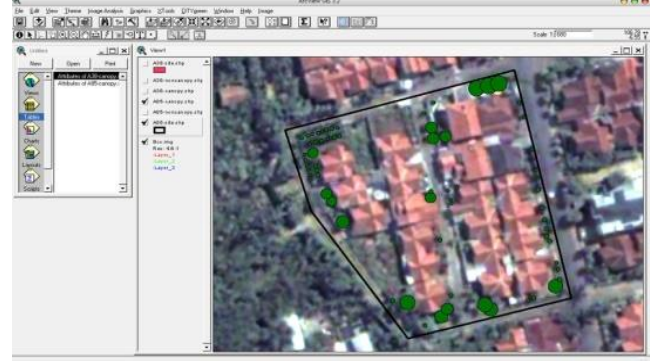

(b) Canopy

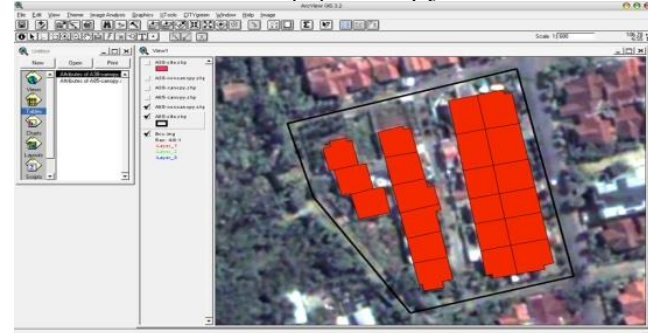

(c) Non canopy

Gambar 5. Hasil Digitasi Theme dalam ArcView

5. Análisis data. Memproses data untuk dianalisis pada menu CITYgreen - Analysis data, Study Area, Run Analysis. Hasilnya berupa sebuah tampilan Analysis Report yang didalamnya berisi keterangan-keterangan yang terbagi kedalam tiga aspek, yaitu statistik tapak (Site Statistics), manfaat ekologi (Ecological Benefits), dan rangkuman manfaat ekonomi (Economic Benefit Summary).

Perhitungan nilai manfaat kanopi dalam kapasitasnya menyimpan dan menyerap karbon pada masing-masing perumahan dilakukan berdasarkan penentuan area sampel analisis. Area analisis dikelompokkan kedalam 3 kelompok site berdasarkan persentase penutupan lahan oleh kanopi pohon, yaitu site-A (0-5\%), site-B (5-10\%), site-C (10-15\%). Hal ini dilakukan untuk memudahkan dalam perhitungan pendugaan nilai kapasitas penyimpanan dan daya serap karbon pada kawasan perumahan.

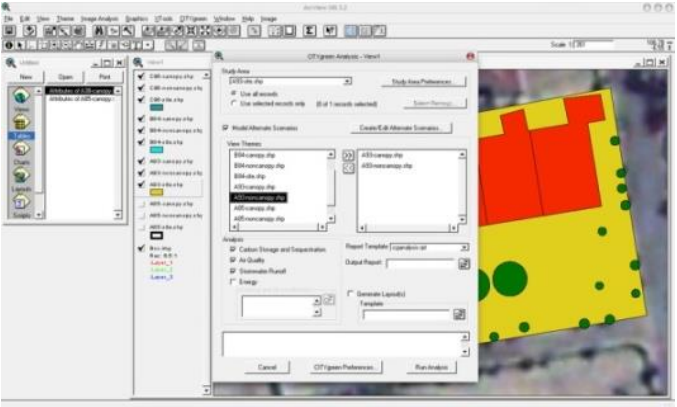

Gambar 6. Tampilan menu CITYgreen Analyze Data dalam ArcView

Adapun rumusan dalam menghitung dan memperkirakan penyimpanan karbon serta daya serap karbon berdasarkan User Manual Citygreen 5.4:

- CITYgreen 5.4 dalam memperkirakan penyimpanan karbon, menggunakan rumus:

Karbon Tersimpan $=\mathrm{A} \times \% \times \mathrm{B}$

Keterangan:

$\mathrm{A}=$ Area kajian (acres)

$\%=$ Persen penutupan pohon

$\mathrm{B}=$ Koefisien penyimpanan karbon (berdasarkan tipe distribusi pohon)

- CITYgreen 5.4 dalam memperkirakan penyerapan karbon, menggunakan rumus:

Tingkat daya serap karbon tahunan $=\mathrm{A} \times \% \times \mathrm{C}$

Keterangan:

$\mathrm{A}=$ Area kajian (acres)

$\%=$ Persen penutupan pohon

$\mathrm{C}=$ Koefisien daya serap karbon (berdasarkan tipe distribusi pohon)

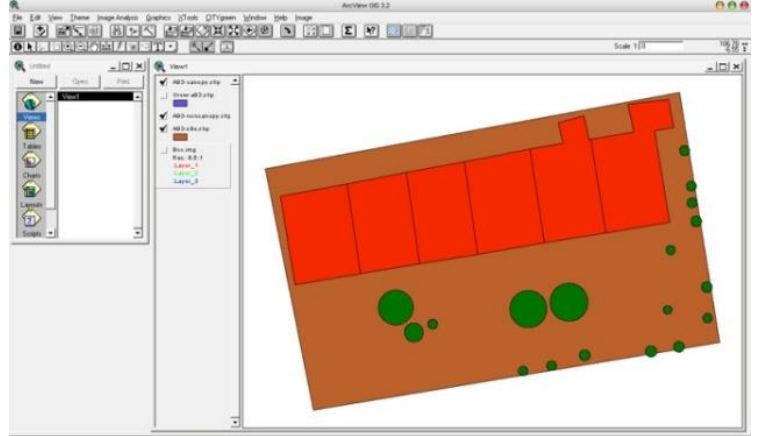

(a) Kanopi pohon eksisting

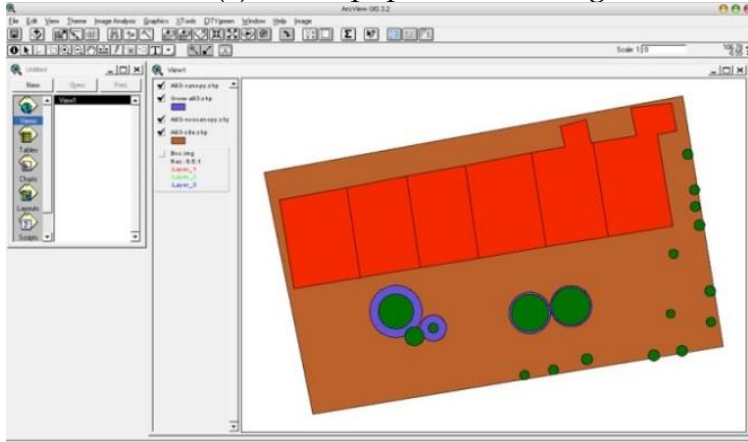

(a) Pertumbuhan kanopi 10 tahun ke depan

Gambar 7. Contoh Tampilan Model Tree Growth dalam ArcView 
Untuk melihat perbandingan nilai manfaat pohon dalam menyimpan dan menyerap karbon, maka dilakukan Model Pertumbuhan Pohon (Model Tree Growth). Hal ini berguna untuk mengetahui bagaimana perkembangan kanopi beberapa tahun ke depan pada suatu wilayah atau area yang dianalisis sehingga dapat diperkirakan tindakan yang harus dilakukan dan sebagai rekomendasi bagi perencanaan selanjutnya.

Pada penelitian ini, untuk dapat membuat perbandingan nilai manfaat kanopi pohon dari kelompok sampel site di kedua perumahan, maka ada beberapa asumsi yang digunakan, yaitu:

1. Sesuai dengan tujuan penelitian, dalam menentukan luasan kanopi yang ideal, maka dilakukan perbandingan dengan menghitung KDB dan KDH kedua perumahan. Secara matematis, menurut Peraturan Gubernur Jawa Barat No. 21 Tahun 2009 untuk menentukan angka KDB bangunan rumah dapat dirumuskan sebagai berikut:

Angka KDB = Luas bangunan lantai dasar $\times 100 \%$ Luas tanah atau blok

Angka KDH $=100 \%-(\mathrm{KDB}+(20 \% \times \mathrm{KDB}))$

Keterangan:

KDB = Koefisien Dasar Bangunan

$\mathrm{KDH}=$ Koefisien Dasar Hijau

2. Asumsi untuk mengetahui besar kecilnya nilai kapasitas karbon dari hasil analisis terhadap RTH (pohon) kedua perumahan.Berdasarkan asumsi dilakukan perbandingan nilai hasil analisis dengan nilai baku mutu Kota Bogor. Berdasarkan data BAPPEDA Kota Bogor (2005), ambien CO dan $\mathrm{CO}_{2}$ adalah 1,307 ton/hari atau setara dengan 477 ton/tahun.

3. Asumsi untuk mengetahui perbandingan nilai manfaat kanopi pohon saat ini dengan beberapa tahun kedepan, maka dilakukan analisis terhadap RTH (pohon) pada 10 dan 20 tahun kedepan dengan dasar pemikiran bahwa pada kelipatan tersebut dapat dilihat perbedaan hasil analisisnya.

\section{HASIL DAN PEMBAHASAN}

\section{Kondisi Umum}

\section{Letak Geografis dan Wilayah Administrasi}

Keterangan mengenai letak geografis dan wilayah administrasi Perumahan BCC dan Perumahan Taman Yasmin dapat dilihat pada Tabel 1.
Tabel 1. Data Letak Geografis dan Wilayah Administrasi

\begin{tabular}{lcc}
\hline \multicolumn{1}{c}{ Jenis Data } & BCC & Taman Yasmin \\
\hline & $06.53^{\circ} \mathrm{LS}-$ & \\
Letak Geografis & $06.56^{\circ} \mathrm{LS}$ & \\
& $106.78^{\circ} \mathrm{BT}$ & \\
Wilayah & Tanah Sareal & Tanah Sareal \\
Administrasi & $129 \mathrm{ha}$ & $103 \mathrm{ha}$ \\
Luas Lahan & $190 \mathrm{mdpl}$ & $190 \mathrm{mdpl}$ \\
Ketinggian &
\end{tabular}

Sumber: BMG Dramaga Bogor (2009)

\section{Topografi dan Tanah}

Menurut Lembaga Penelitian Tanah Bogor, jenis tanah yang terdapat di kedua perumahan adalah jenis tanah Latosol. Kawasan Bukit Cimanggu City (BCC) dan Kawasan Taman Yasmin memiliki topografi yang relatif datar dengan distribusi kemiringan berkisar 0-5\%. Kesesuaian berdasarkan kemiringan lereng pada kedua kawasan perumahan tersebut telah memenuhi kriteria kesesuaian lahan perumahan, yaitu dibangun pada lahan dengan kemiringan $0-15 \%$ (Standar Nasional Indonesia, 2004).

\section{Iklim}

Iklim di Kabupaten Bogor menurut klasifikasi Schmidt dan Ferguson,termasuk Iklim Tropis tipe A (Sangat Basah) di bagian selatan dan tipe B (Basah) di bagian utara. Suhu berkisar rata-rata antara $20^{\circ} \mathrm{C}$ sampai $30{ }^{\circ} \mathrm{C}$. Curah hujan tahunan antara $2.500 \mathrm{~mm}$ sampai lebih dari $5.000 \mathrm{~mm} /$ tahun, kecuali di wilayah bagian utara curah hujannya kurang dari $2.500 \mathrm{~mm} /$ tahun. Data iklim pada kedua perumahan umumnya tidak terdapat perbedaan. Data iklim perumahan BCC dan perumahan Taman Yasmin disajikan pada Tabel 2.

Tabel 2. Data iklim perumahan Bukit Cimanggu City (BCC) dan perumahan Taman Yasmin Periode Mei 2009-Mei 2010

\begin{tabular}{llc}
\hline Jenis Data & BCC & Taman Yasmin \\
\hline Suhu Maksimum $\left({ }^{\circ} \mathrm{C}\right)$ & 27,7 & 27,7 \\
Suhu Minimum $\left({ }^{\circ} \mathrm{C}\right)$ & 25,3 & 25,3 \\
Suhu Rata-rata $\left({ }^{\circ} \mathrm{C}\right)$ & 26,4 & 26,4 \\
Curah Hujan Rata-rata $(\mathrm{mm})$ & 310,9 & 310,9 \\
Bulan Basah Tertinggi & Okt-09 & Okt-09 \\
Bulan Basah Terendah & Apr-10 & Apr-10 \\
\hline
\end{tabular}

\section{Vegetasi}

Vegetasi yang berada di perumahan BCC dan Taman Yasmin beraneka ragam jenisnya. Vegetasi dibagi kedalam tiga kelompok berdasarkan ketinggian bentuknya yaitu groundcover, semak, dan pohon. Vegetasi tersebut menyebar di seluruh kawasan perumahan. Dari hasil inventarisasi di lapang, perumahan BCC dan perumahan Taman Yasmin untuk vegetasi pohondidominasi oleh pohon mangga, jambu, rambutan, dan cemara. 


\section{RTH Perumahan}

Ruang Terbuka Hijau (RTH) di perumahan BCC dan Taman Yasmin terdiri dari beberapa jenis pengelompokan yang berbeda-beda. Jenis RTH yang ada mempunyai manfaat atau fungsi yang berbeda-beda. Berdasarkan hasil kajian dan survey lapang, jenis RTH yang terdapat di Perumahan BCC dan Taman Yasmin Bogor dengan mengacu pada Permendagri No. 1 Tahun 2007, pasal 6, tentang klasifikasi dan jenis RTH, kedua perumaha tersebut memiliki RTH, yaitu diantaranya taman rumah, taman lingkungan, lapangan olah raga atau lapangan rumput, taman di dekat danau, dan median jalan.

Proses analisis dibagi menjadi dua kawasan yang berbeda, yaitu Kawasan Perumahan Bukit Cimanggu City dengan analisis 26 site sampel dan Kawasan Perumahan Taman Yasmin Bogor dengan analisis 35 site sampel. Pemilihan site sampel didasari oleh persentase penutupan lahan kanopi pohon. Pengelompokkan site sampel pada masing-masing perumahan dapat dilihat pada Tabel 3.

Tabel 3. Pengelompokkan Site Sampel di Perumahan

\begin{tabular}{llcc}
\hline \multirow{2}{*}{$\begin{array}{c}\text { Nama } \\
\text { Perumahan }\end{array}$} & Kelompok & \multicolumn{2}{c}{ Jumlah Site } \\
\cline { 3 - 4 } BCC & Site & Total & Sampel \\
& SA_X_xx & 39 & 6 \\
& SB_X_xx & 32 & 14 \\
& SC_X_xx & 9 & 6 \\
\hline Yasmin & SA_SY_yy & 34 & 15 \\
& SB_SY_yy & 26 & 12 \\
& SC_SY_yy & 15 & 8 \\
\hline
\end{tabular}

Keterangan:

Dua huruf pertama adalah nama kelompok site ( $\mathrm{SA}=$ site $\mathrm{A}$, $\mathrm{SB}=$ site $-\mathrm{B}, \mathrm{SC}=$ site $-\mathrm{C}$ )

$\mathrm{X}=$ Nama blok di perumahan $\mathrm{BCC}, \mathrm{xx}=$ urutan site

$\mathrm{Y}=$ Nama sektor di perumahan Taman Yasmin, yy=urutan site $\mathrm{BCC}=$ Bukit Cimanggu City

\section{Hasil Analisis GIS dengan Ekstensi CITYgreen 5.4}

Hasil analisis CITYgreen 5.4 untuk Carbon Storage and Sequestration (karbon tersimpan dan daya serap karbon) dengan menggunakan asumsi dan kriteria sesuai metodologi diperoleh hasil yang beragam. Berdasarkan data spasial dan data atribut yang dianalisis dengan metode GIS menggunakan ArcView 3.2 serta ekstensi CITYgreen 5.4, untuk pendugaan karbon tersimpan dan daya serap karbon pada kelompok site A, site B, dan site $\mathrm{C}$ dapat dilihat pada tabel-tabel berikut ini.
Tabel 4. Pendugaan Karbon Tersimpan dan Daya Serap Karbon pada Kelompok Site Sampel di BCC

\begin{tabular}{lcccc}
\hline \multirow{2}{*}{ Jenis data } & \multicolumn{3}{c}{ Area Analisis } & \multirow{2}{*}{ Total } \\
\cline { 2 - 4 } & Site A & Site B & Site C & \\
\hline Luas Area (ha) & 2,96 & 6,45 & 3,10 & 12,51 \\
\hline $\begin{array}{l}\text { Luas Lahan } \\
\text { Terbangun (ha) }\end{array}$ & 1,68 & 3,38 & 1,79 & 6,85 \\
\hline $\begin{array}{l}\text { Luas Lahan Kanopi } \\
\text { (ha) }\end{array}$ & 0,12 & 0,49 & 1,79 & 2,40 \\
\hline Jumlah Pohon & 137 & 504 & 212 & 853 \\
\hline $\begin{array}{l}\text { Karbon Tersimpan } \\
\text { (kg) }\end{array}$ & 9.000 & 38.000 & 27.000 & 74.000 \\
\hline $\begin{array}{l}\text { Daya Serap Karbon } \\
\text { (kg/th) }\end{array}$ & 199,59 & 816,47 & 544,32 & $1.560,38$ \\
\hline
\end{tabular}

Sumber: Hasil Analisis, 2010

Tabel 5. Pendugaan Karbon Tersimpan dan Daya Serap Karbon pada Kelompok Site Sampel di Taman Yasmin

\begin{tabular}{|c|c|c|c|c|c|}
\hline \multirow{2}{*}{\multicolumn{2}{|c|}{ Jenis data }} & \multicolumn{3}{|c|}{ Area Analisis } & \multirow{2}{*}{ Total } \\
\hline & & Site A & Site B & Site C & \\
\hline \multicolumn{2}{|l|}{ Luas Area (ha) } & 12,19 & 15,15 & 10,28 & 37,62 \\
\hline \multicolumn{2}{|c|}{$\begin{array}{l}\text { Luas Lahan } \\
\text { Terbangun (ha) }\end{array}$} & 4,65 & 6,60 & 3,76 & 15,01 \\
\hline \multicolumn{2}{|l|}{$\begin{array}{l}\text { Luas Lahan } \\
\text { Kanopi (ha) }\end{array}$} & 0,47 & 0,95 & 1,07 & 2,49 \\
\hline \multicolumn{2}{|l|}{ Jumlah Pohon } & 588 & 910 & 567 & 2.065 \\
\hline \multicolumn{2}{|c|}{$\begin{array}{l}\text { Karbon } \\
\text { Tersimpan }(\mathrm{kg})\end{array}$} & 38.000 & 75.000 & 88.000 & 201.000 \\
\hline \multicolumn{2}{|c|}{$\begin{array}{l}\text { Daya Serap } \\
\text { Karbon }(\mathrm{kg} / \mathrm{th})\end{array}$} & 752,99 & $1.505,92$ & $1.660,14$ & $3.919,05$ \\
\hline \multicolumn{6}{|c|}{ Sumber: Hasil Analisis, 2010} \\
\hline \multicolumn{6}{|c|}{$\begin{array}{l}\text { Tabel 6. Pendugaan Karbon Tersimpan dan Daya Serap } \\
\text { Karbon per hektar (ha) pada Kelompok Site Sampel } \\
\text { di Perumahan }\end{array}$} \\
\hline Perumahan & \multicolumn{2}{|c|}{$\begin{array}{l}\text { Kelo } \\
\text { mpok } \\
\text { Site }\end{array}$} & $\begin{array}{c}\text { Luas } \\
\text { Area (ha) }\end{array}$ & $\begin{array}{l}\text { Karbon } \\
\text { tersimpan } \\
(\mathrm{kg} / \mathrm{ha}) \\
\end{array}$ & $\begin{array}{c}\text { Daya Serap } \\
\text { Karbon } \\
\text { (kg/ha/th) }\end{array}$ \\
\hline \multirow[t]{3}{*}{ BCC } & \multicolumn{2}{|c|}{ Site A } & 2,96 & $3.040,54$ & 67,43 \\
\hline & \multicolumn{2}{|c|}{ Site B } & 6,45 & $5.891,47$ & 126,58 \\
\hline & \multicolumn{2}{|c|}{ Site C } & 3,10 & $8.709,68$ & 175,59 \\
\hline \multicolumn{4}{|c|}{ Rata-rata per ha } & $5.880,56$ & 123,20 \\
\hline \multirow[t]{3}{*}{ Yasmin } & Sit & & 19 & $3.117,31$ & 61,77 \\
\hline & Sit & & 15 & $4.950,50$ & 99,40 \\
\hline & Sit & & 28 & $8.560,31$ & 161,49 \\
\hline Rata & -rat & er ha & & $5.542,71$ & 107,55 \\
\hline
\end{tabular}

Sumber: Hasil Analisis, 2010 


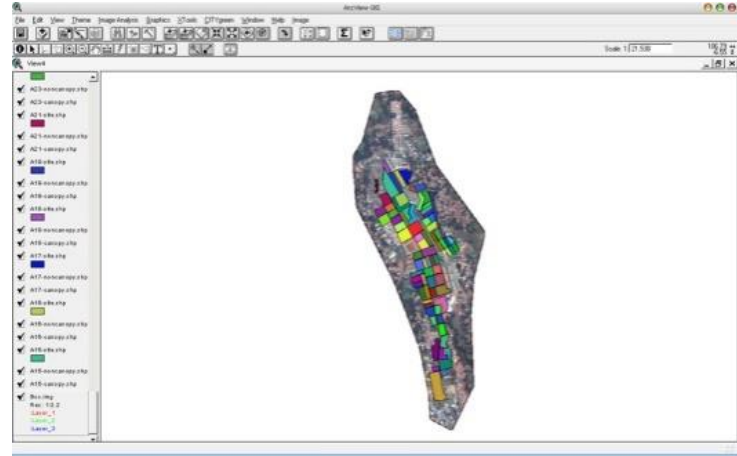

(a) BCC

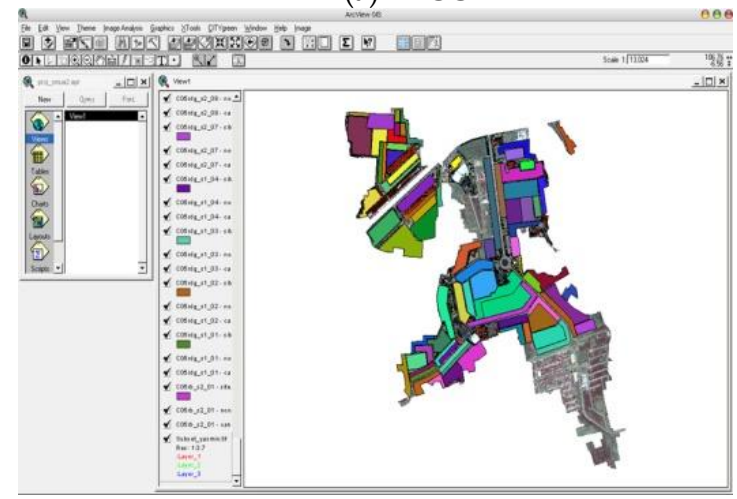

(b) Yasmin

Gambar 8. Tampilan Hasil Digitasi Seluruh Kelompok Site pada Perumahan

Tabel 7. Perbandingan Nilai Karbon Tersimpan (kg) berdasarkan Tahun Pertumbuhan

\begin{tabular}{|c|c|c|c|c|}
\hline \multirow{2}{*}{ Perumahan } & \multirow{2}{*}{$\begin{array}{c}\text { Kelompok } \\
\text { Site }\end{array}$} & \multicolumn{3}{|c|}{ Karbon Tersimpan (kg) } \\
\hline & & Saat ini & 10 th & 20 th \\
\hline \multirow[t]{3}{*}{ BCC } & Site $\mathrm{A}$ & 9.000 & 10.000 & 11.000 \\
\hline & Site $\mathrm{B}$ & 38.000 & 41.000 & 45.000 \\
\hline & Site C & 27.000 & 28.000 & 34.000 \\
\hline \multicolumn{2}{|c|}{ Total } & 74.000 & 79.000 & 90.000 \\
\hline \multirow[t]{3}{*}{ Yasmin } & Site A & 38.000 & 43.000 & 50.000 \\
\hline & Site B & 75.000 & 99.000 & 119.000 \\
\hline & Site C & 88.000 & 87.000 & 91.000 \\
\hline \multicolumn{2}{|c|}{ Total } & 201.000 & 229.000 & 260.000 \\
\hline
\end{tabular}

Tabel 8. Perbandingan Nilai Daya Serap Karbon (kg/tahun) berdasarkan Tahun Pertumbuhan

\begin{tabular}{|c|c|c|c|c|}
\hline \multirow[t]{2}{*}{ Perumahan } & \multirow{2}{*}{$\begin{array}{c}\text { Kelompok } \\
\text { Site }\end{array}$} & \multicolumn{3}{|c|}{$\begin{array}{c}\text { Daya Serap Karbon } \\
(\mathrm{kg} / \text { tahun })\end{array}$} \\
\hline & & Saat ini & 10 th & 20 th \\
\hline \multirow[t]{3}{*}{ BCC } & Site A & 199,59 & 208,66 & 172,37 \\
\hline & Site B & 816,47 & 789,25 & 707,60 \\
\hline & Site C & 544,32 & 562,46 & 344,72 \\
\hline \multicolumn{2}{|c|}{ Total } & $1.560,38$ & $1.560,37$ & $1.224,69$ \\
\hline \multirow[t]{3}{*}{ Yasmin } & Site A & 752,99 & 898,13 & 762,05 \\
\hline & Site B & $1.505,92$ & $2.023,06$ & $1.787,18$ \\
\hline & Site C & $1.660,14$ & $1.596,67$ & $1.415,23$ \\
\hline \multicolumn{2}{|c|}{ Total } & $3.919,05$ & $4.517,86$ & $3.964,46$ \\
\hline
\end{tabular}

Sumber: Hasil Analisis, 2010

\section{Pembahasan Hasil Analisis CITYgreen 5.4}

1. Perbandingan Luas Penutupan Lahan oleh Kanopi Pohon dengan Non Kanopi Pohon (Lahan Terbangun)

Berdasarkan hasil analisis CITYgreen tersebut diatas dapat dilihat bahwa:

1) Perbandingan luas penutupan lahan oleh kanopi pohon dengan non kanopi pohon (lahan terbangun), yaitu:

a. Perumahan BCC dengan luas total area analisis sebesar 12,51 ha memiliki perbandingan luas penutupan lahan oleh kanopi pohon dengan non kanopi pohon (lahan terbangun), yaitu 19,18\% (2,40 ha): 54,76\% (6,85 ha); sisanya adalah 26,06\% berupa jalan, lahan kosong,lahan parkir, bangunan selain rumah dan ruko, median jalan, kolam, danau, dan lain-lain.

b. Perumahan Yasmin dengan luas total area analisis sebesar 37,62 ha memiliki perbandingan luas penutupan lahan oleh kanopi pohon dengan non kanopi pohon (lahan terbangun), yaitu $6,62 \%$ (2,49 ha) : 39,90\% (15,01 ha); sisanya adalah 53,48\% berupa jalan, lahan kosong, lahan parkir, bangunan selain rumah dan ruko, median jalan, kolam, danau, dan lain-lain.

Untuk melihat kecukupan persentase penutupan lahan oleh kanopi pohon di kedua perumahan, maka perlu dibandingkan dengan KDB dan $\mathrm{KDH}$ di kedua perumahan. Berdasarkan perhitungan nilai KDB dan $\mathrm{KDH}$ di kedua perumahan dihasilkan data sebagai berikut:

Tabel 9. Pendugaan Nilai KDB dan KDH pada Area Analisis Kelompok Site Sampel di Perumahan

\begin{tabular}{lccc}
\hline \multirow{2}{*}{ Perumahan } & $\begin{array}{c}\text { Kelompok } \\
\text { Site }\end{array}$ & KDB (\%) & KDH (\%) \\
\hline BCC & Site A & 56,76 & 31,89 \\
& Site B & 52,40 & 37,12 \\
& Site C & 57,74 & 30,71 \\
\hline Yasmin & Rata-rata & 55,63 & 33,24 \\
& Site A & 38,15 & 54,22 \\
& Site B & 43,56 & 47,72 \\
& Site C & 36,58 & 56,11 \\
\hline \multicolumn{2}{c}{ Rata-rata } & 39,43 & 52,69 \\
\hline
\end{tabular}

Dilihat dari hasil perhitungan pada Tabel 9, maka menurut Perda No. 6 Tahun 1999 KDB di Perumahan BCC termasuk kedalam klasifikasi sedang (40-60\%) sedangkan KDB Perumahan Yasmin termasuk kedalam klasifikasi renggang/tidak padat $(<40 \%)$. Jika dibandingkan dengan standar KDH minimal menurut Perda No. 6 Tahun 1999, maka angka KDH kedua perumahan dapat dikatakan sudah memenuhi standar $\mathrm{KDH}$ minimal, yaitu diatas $20 \%$. Oleh karena itu, dapat 
disimpulkan bahwa luas RTH (pohon) di kedua perumahan sudah mencukupi atau ideal.

2) Jumlah pohon di Perumahan Yasmin lebih banyak daripada di Perumahan BCC, namun jumlah pohon per ha di Perumahan Yasmin lebih sedikit dibandingkan dengan di Perumahan BCC, yaitu di Perumahan Yasmin adalah 55 pohon/ha sedangkan Perumahan BCC adalah 68 pohon/ha (Tabel 4 dan 5). Hal ini dipengaruhi oleh besar kecilnya luas area analisis pada masing-masing Perumahan.

2. Pendugaan Manfaat Vegetasi Pohon sebagai Penyimpan dan Penyerap Karbon di Perumahan

Berdasarkan hasil analisis CITYgreen 5.4 untuk manfaat pohon sebagai penyimpan dan penyerap karbon adalah sebagai berikut:

1) Kelompok site $\mathrm{C}$ di kedua perumahan memiliki luas penutupan lahan oleh kanopi lebih besar dari site A dan site B (Tabel 4 dan 5). Selain itu, site C juga memiliki jumlah karbon tersimpan dan daya serap karbon per ha paling besar (Tabel 6).

Pada Tabel 6 dapat dilihat bahwa luas penutupan lahan oleh kanopi pohon sangat berpengaruh terhadap jumlah karbon tersimpan dan daya serap karbon. Site C dengan luas penutupan lahan oleh kanopi pohon paling besar memiliki jumlah karbon tersimpan dan daya serap karbon per ha lebih besar dibandingkan site A dan site $\mathrm{B}$. Hal ini sesuai dengan rumus umum yang digunakan pada CITYgreen dimana karbon tersimpan dan daya serap karbon berbanding lurus dengan persentase penutupan lahan oleh pohon.

2) Jumlah pohon per ha pada site B lebih banyak dibandingkan jumlah pohon per ha pada site C (Tabel 5). Namun, jumlah karbon tersimpan dan daya serap karbon per ha pada site $\mathrm{C}$ lebih besar dibandingkan site B (Tabel 6).

Selain disebabkan luas penutupan lahan oleh kanopi pohon pada site $\mathrm{C}$ lebih besar dari site $\mathrm{B}$, hal ini juga disebabkan rata-rata umur pohon pada site $C$ relatif lebih tua dibandingkan site B. Pohon dewasa/tua memiliki lebar tajuk dan diameter batang yang lebih besar dibandingkan dengan pohon muda. Semakin besar ukuran pohon (biomassa pohon), maka semakin besar jumlah karbon tersimpan.Kapasitas karbon tersimpan juga dipengaruhi oleh daya serap karbon. Semakin tinggi jumlah daya serap karbon, maka semakin besar kapasitas karbon tersimpan.
3) Rata-rata karbon tersimpan dan daya serap karbon per ha (luas area analisis) di Perumahan BCC lebih besar daripada di Perumahan Yasmin (Tabel 6).

Hal ini disebabkan perbedaan persentase penutupan oleh kanopi pohon dan jumlah pohon per ha di kedua perumahan. Perumahan BCC memiliki persentase penutupan lahan oleh kanopi pohon sebesar $19,18 \%$ dan jumlah pohon per ha sebanyak 68 pohon/ha. Sementara itu, Perumahan Yasmin memiliki persentase penutupan lahan oleh kanopi pohon sebesar $6,62 \%$ dan jumlah pohon per ha sebanyak 55 pohon/ha (Tabel 4 dan 5).

4) Berdasarkan hasil perbandingan antara karbon tersimpan dan daya serap karbon dengan baku mutu lingkungan Kota Bogor (2005), dihasilkan data sebagai berikut:

a. Jika diasumsikan Kota Bogor menghasilkan ambien $\mathrm{CO}$ dan $\mathrm{CO}_{2}$ sebesar 0.04 ton/ha/tahun, maka ambient $\mathrm{CO}$ dan $\mathrm{CO}_{2}$ di rea analisis Perumahan BCC dan Taman Yasmin masingmasing sebesar 0,50 ton/tahun dan 1,50 ton/tahun.

b. Jika kita bandingkan hasilnya dari hasil analisis CITYgreen 5.4 pada penelitian ini, kemampuan RTH (pohon) pada area analiss di perumahan BCC dalam menyerap karbon sebesar 1,56 ton/tahun sedangkan perumahan Yasmin sebesar 3,92 ton/tahun. Maka dengan keberadaan RTH (pohon) kedua perumahan saat ini masih mencukupi untuk menyerap $\mathrm{CO}_{2}$ dan polutan $\mathrm{CO}$ yang dihasilkan. Namun demikian, untuk mengantisipasi lonjakan konsentrasi $\mathrm{CO}_{2}$ dan polutan $\mathrm{CO}$ di udara pada tahun-tahun mendatang diharapkan penambahan luasan RTH (pohon) serta pemilihan jenis pohon yang memiliki umur panjang, kapasitas, dan daya serap karbon yang tinggi.

3. Perbandingan Kondisi Perumahan Saat Ini dan Beberapa Tahun Kedepan dengan Simulasi Model Tree Growth dalam CITYgreen 5.4

Umur pohon dapat berpengaruh terhadap besar kapasitas karbon tersimpan dan daya serap karbon. Berdasarkan hasil analisis dengan menggunakan CITYgreen 5.4:

1) Jumlah karbon tersimpan $(\mathrm{kg} /$ tahun$)$ di perumahan BCC dan perumahan Yasminpada 10 dan 20 tahun kedepan akan mengalami kenaikan (Tabel 7).

Hal ini disebabkan umur pohon yang semakin tua. Pohon yang tua telah mencapai kondisi dimana 
ukuran tajuk, batang, dan daun maksimum. Berdasarkan hasil analisis dan inventarisasi, site-site dengan pohon-pohon besar (diameter pohon $>20$ $\mathrm{cm}$ ) memiliki jumlah karbon tersimpan lebih banyak dibandingkan dengan site-site dengan pohon-pohon yang masih kecil (diameter batang $<10 \mathrm{~cm}$ ). Hal ini sesuai dengan yang dikemukakan McPherson dan Simpson (1999) bahwa jumlah total dari karbon tersimpan di atas 60 tahun oleh pohon yang pertumbuhannya lambat (berumur panjang) akan lebih besar dibandingkan dengan pohon pertumbuhannya cepat tetapi berumur pendek.

2) Daya serap karbon pada pertumbuhan 20 tahun kedepanakan mengalami penurunan (Tabel 8).

Pohon yang tua, memiliki laju fotosintesis yang relatif rendah dibandingkan pohon yang masih muda karena daun yang telah mencapai ukuran maksimum serta klorofil daun mulai rusak.

Salah satu contoh hasil analisis CITYgreen 5.4 dengan menggunakan Model Tree Growth dapat dilihat pada Gambar 9, 10, dan 11.

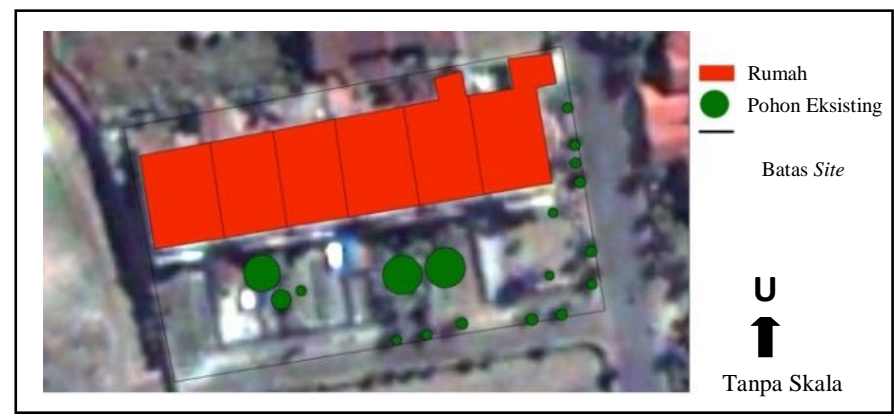

Gambar 9. Hasil Analisis CITYgreen 5.4 pada Site SA_G_01 dalam ArcView

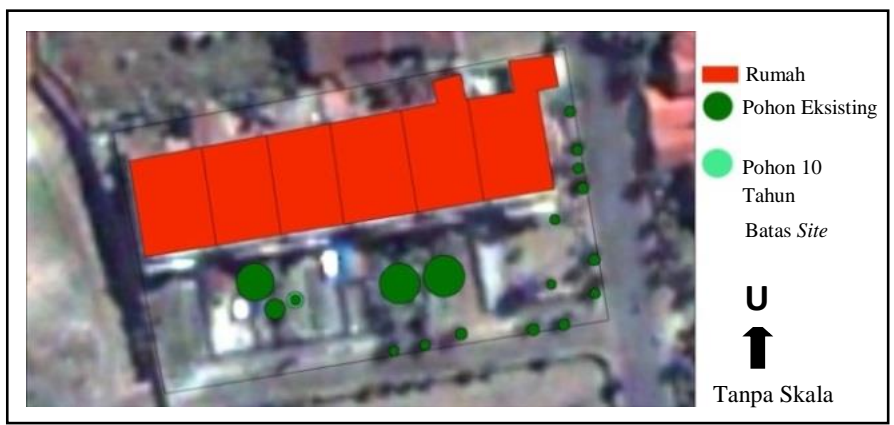

Gambar 10. Hasil Analisis CITYgreen 5.4 pada Site SA_G_01 dengan Model Tree Growth pertumbuhan kanopi 10 tahun kedepan dalam ArcView

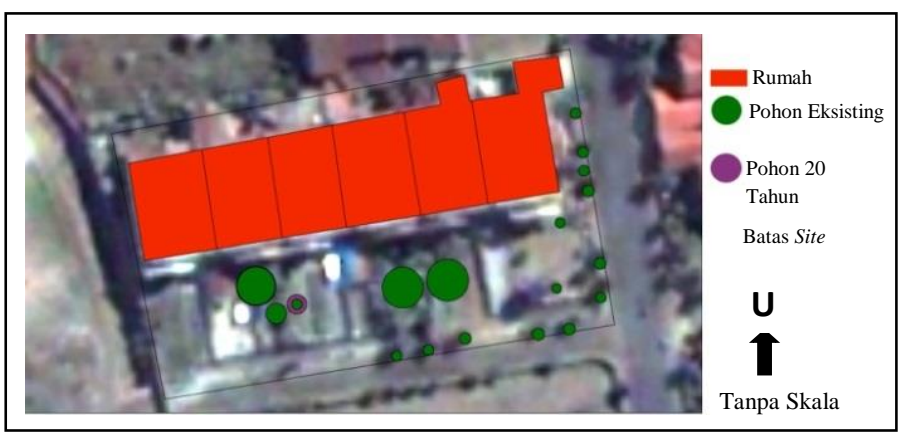

Gambar 11. Hasil Analisis CITYgreen 5.4 pada Site SA_G_01 dengan Model Tree Growth pertumbuhan kanopi 20 tahun ke depan dalam ArcView

\section{SIMPULAN}

\section{Simpulan}

Vegetasi pohon di suatu lingkungan perumahan dapat memberikan manfaat dalam penyimpanan dan penyerapan karbon. Perumahan BCC dengan luas total area analisis sebesar 12,51 ha memiliki perbandingan luas penutupan lahan oleh kanopi pohon dengan non kanopi pohon (lahan terbangun) lebih besar, yaitu $19,18 \% \quad(2,40$ ha): $54,76 \% \quad(6,85$ ha $)$ dibandingkan Perumahan Yasmin dengan luas total area analisis sebesar 37,62 ha, yaitu 6,62\% (2,49 ha) : 39,90\% (15,01 ha). Berdasarkan hasil perhitungan KDB dan KDH di kedua perumahan maka dapat dikatakan bahwa luas RTH (pohon) di kedua perumahan sudah mencukupi atau ideal, namun dalam hal kecukupan kebutuhan oksigen bagi manusia belum dapat tercukupi. Oleh karena itu, perlu adanya penambahan luas RTH (pohon) pada masing-masing perumahan.

Rata-rata karbon tersimpan per ha (luas area analisis) di Perumahan BCC dan Yasmin, masing-masing adalah sebesar $5.880,56 \mathrm{~kg} / \mathrm{ha}$ dan $5.542,71 \mathrm{~kg} /$ ha sedangkan rata-rata daya serap karbon per ha (luas area analisis) masing-masing adalah sebesar $123,20 \mathrm{~kg} / \mathrm{ha} /$ tahun dan $107,55 \mathrm{~kg} / \mathrm{ha} /$ tahun. Keberadaan pepohonan masih dapat mencukupi dalam menyimpan dan menyerap karbon yang dihasilkan, namun untuk mengantisipasi meningkatnyakonsentrasi $\mathrm{CO}_{2}$ di udara pada tahuntahun mendatang diharapkan penambahan luasan RTH (pohon) serta pemilihan jenis pohon yang memiliki umur panjang, kapasitas, dan daya serap karbon yang tinggi. Kapasitas karbon tersimpan dan daya serap karbon dapat dipengaruhi oleh beberapa faktor, yaitu diantaranya luas penutupan lahan oleh kanopi pohon, jumlah pohon, jenis pohon, umur pohon, kesehatan pohon dan laju fotosintesis.

\section{Saran}

1. Pihak pengembang perumahan perlu memperhitungkan keberadaan vegetasi pohon dan 


\section{LUKMANNIAH, FATIMAH}

pemilihan jenis pohon dalam perencanaan pengembangan kawasan perumahan.

2. Perlu diadakannya pertimbangan keberadaan taman rumah dan taman lingkungan di sekitar kawasan perumahan sebagai nilai lebih yang ditawarkan pihak pengembang perumahan.

3. Masyarakat di sekitar perumahan perlu menyadari pentingnya keberadaan pohon sebagai elemen lanskap dalam manfaatnya untuk menyimpan dan menyerap karbon di udara.

4. Perlu diadakan penelitian lebih lanjut tentang manfaat vegetasi lainnya sebagai elemen lanskap seperti semak dan rumput terhadap penyimpanan dan penyerapan karbon di kawasan perumahan.

5. Perlu diadakan penelitian lebih lanjut tentang manfaat pohon dilihat dari aspek-aspek yang lain dalam Analisis CITYgreen.

\section{DAFTAR PUSTAKA}

American Forest. 2002. CITYgreen 5.0:User Manual. Washington DC: American Forest. 187 page.

Dahlan EN. 2007. Analisis Kebutuhan Luasan Hutan Kota sebagai Sink Gas $\mathrm{CO}_{2}$ Antropogenik dari Bahan Bakar Minyak dan Gas di Kota Bogor dengan Pendekatan Sistem Dinamik [disertasi]. Bogor. Program Studi Ilmu Pengetahuan Kehutanan, Sekolah Pasca Sarjana, Institut Pertanian Bogor.

McPherson EG dan Simpson JR. 1999. Carbon Dioxide Rreduction Through Urban Forestry: Guidelines for Professional and Volunteer Tree Planters. California: U.S. Department of Agriculture, Forest Service.

Purwaningsih S. 2007. Kemampuan Serapan Karbondioksida pada Tanaman Hutan Kota di Kebun Raya Bogor [skripsi]. Bogor. Departemen Konservasi Sumberdaya Hutan dan Ekowisata, Fakultas Kehutanan, Institut Pertanian Bogor.

Suryadi Y. 2008. Dinamika Pola Pemanfaatan Lahan dan Pengendalian Menuju Pembangunan Kota Bogor yang Berkelanjutan. [Tesis]. Program Pascasarjana, Institut Pertanian Bogor. 136 hal. 